Research, Society and Development, v. 10, n. 16, e207101623576, 2021

(CC BY 4.0) | ISSN 2525-3409 | DOI: http://dx.doi.org/10.33448/rsd-v10i16.23576

\title{
Properties of tofu coagulated with Cardoon flower (Cynara Cardunculus L.)
}

\author{
Propriedades do tofu coagulado com flor Cardoon (Cynara Cardunculus L.) \\ Propiedades del tofu coagulado con flor de Cardo (Cynara Cardunculus L.)
}

Received: 11/19/2021 | Reviewed: 11/28/2021 | Accept: 11/29/2021| Published: 12/11/2021

Glaciela Cristina Rodrigues da Silva Scherer

ORCID: https://orcid.org/0000-0003-4981-0605

Regional Integrated University of Alto Uruguai e das Missões, Brazil

E-mail: glaciela.cristina@yahoo.com.br

Rosicler Colet

ORCID: https://orcid.org/0000-0001-8589-0804

Regional Integrated University of Alto Uruguai e das Missões, Brazil E-mail: rosicler.colet@yahoo.com.br

Darlene Cavalheiro

ORCID: https://orcid.org/0000-0003-2556-0277 State University of Santa Catarina, Brazil E-mail: darlene.cavalheiro@udesc.br

Clarice Steffens

ORCID: https://orcid.org/0000-0003-4394-125X Regional Integrated University of Alto Uruguai e das Missões, Brazil E-mail: clarices@uricer.edu.br

Eunice Valduga

ORCID: https://orcid.org/0000-0002-2553-0740 Regional Integrated University of Alto Uruguai e das Missões, Brazil E-mail: veunice@uricer.edu.br

Mercedes Concórdia Carrão-Panizzi

ORCID: https://orcid.org/0000-0003-2979-7079

Brazilian Agricultural Research Corporation, Brazil E-mail: mercedes.panizzi@embrapa.br

Juliana Steffens

ORCID: https://orcid.org/0000-0001-6607-2283 Regional Integrated University of Alto Uruguai e das Missões, Brazil E-mail: julisteffens@uricer.edu.br

Jamile Zeni

ORCID: https://orcid.org/0000-0002-0529-2212 Regional Integrated University of Alto Uruguai e das Missões, Brazil E-mail: jamilezeni@uricer.edu.br

\begin{abstract}
Tofu was elaborated using water-soluble extract of soybean grains from the cultivar BRS 267 with cardoon flower $(C$. Cardunculus L.), as coagulant as an alternative to the traditional coagulant magnesium chloride. The tofu were evaluated in relation to physical, chemical, microbiological and sensory properties during 14 days. Was obsersed for the tofu coagulated with cardoon flower that the moisture, $\mathrm{pH}$, total mineral, protein, and syneresis decreased with the storage, while Kunitz Trypsin Inhibitor, ureatic activity and phytic acid did not change. It was also obtained a positive effect for color $\left(\mathrm{L}^{*}, \mathrm{a}^{*}\right)$ parameters, phytic acid, yield, syneresis, and acceptance. The textural properties, showed a tendency to increase of hardness and stickiness, while springiness and cohesiveness decreased during storage. Structurally, presented irregular-shaped, small pores or cavities. The sensory analysis, showed has great acceptance and purchase intent. Then, the cardoon flower can be used as vegetal coagulant improving the quality properties of tofu, in relation to magnesium chloride.
\end{abstract}

Keywords: Texture; Acceptance; Vegetable coagulante; Storage.

\section{Resumo}

O tofu foi elaborado usando extrato hidrossolúvel dos grãos de soja da cultivar BRS 267, utilizando a flor do cardo (C. Cardunculus L.), como coagulante alternativo ao processo tradicional com cloreto de magnésio. O tofu foi avaliado em relação as propriedades físicas, químicas, microbiológicas e sensoriais durante 14 dias. Foi observado para o tofu coagulado com a flor do cardo que a umidade, o $\mathrm{pH}$, o mineral total, a proteína e a sinérese diminuíram com o armazenamento, enquanto o Inibidor de Tripsina de Kunitz, a atividade ureática e o ácido fítico não se alteraram. Foi também observado um efeito positivo para os parâmetros de cor $\left(\mathrm{L}^{*}, \mathrm{a} *\right)$, ácido fítico, rendimento, sinérese e aceitação. As propriedades texturais mostraram uma tendência de aumentar a dureza e a gomosidade, 
enquanto a elasticidade e a coesividade diminuíram durante o armazenamento. Estruturalmente, apresentou pequenos poros ou cavidades irregulares. A análise sensorial mostrou grande aceitação e intenção de compra. Então, a flor do cardo pode ser utilizada como coagulante vegetal melhorando as propriedades de qualidade do tofu, em relação ao cloreto de magnésio.

Palavras-chave: Textura; Aceitação; Coagulante vegetal; Estocagem.

\section{Resumen}

El tofu se preparó utilizando extracto hidrosoluble de soja del cultivar BRS 267, utilizando la flor de cardo ( $C$. Cardunculus L.), como coagulante alternativo al proceso tradicional con cloruro de magnesio. El tofu se evaluó por sus propiedades físicas, químicas, microbiológicas y sensoriales durante 14 días. Se observó para el tofu coagulado con la flor de cardo que la humedad, el $\mathrm{pH}$, el mineral total, la proteína y la sinéresis disminuyeron con el almacenamiento, mientras que el inhibidor de tripsina de Kunitz, la actividad ureática y el ácido fítico no cambiaron. También se observó un efecto positivo para los parámetros de color ( $\mathrm{L}^{*}$, a *), ácido fítico, rendimiento, sinéresis y aceptación. Las propiedades texturales mostraron una tendencia a aumentar la dureza y la gomina, mientras que la elasticidad y la cohesión disminuyeron durante el almacenamiento. Estructuralmente presentaba poros pequeños o cavidades irregulares. El análisis sensorial mostró una gran aceptación e intención de compra. Luego, la flor de cardo se puede utilizar como coagulante vegetal, mejorando las propiedades de calidad del tofu, en relación al cloruro de magnesio.

Palabras clave: Textura; Aceptación; Coagulante vegetal; Almacenamiento.

\section{Introduction}

Tofu is a nutritious traditional oriental food with an increasing worldwide demand (Nikolić et al., 2017). It can be used for vegan individuals as a substitute of animal products, due to its high quality protein compared to meat, fish and cheese (Khoder et al., 2020). In addition, it presents other important nutritional qualities, such as free cholesterol, minerals and polyunsaturated fatty acids (Losado, Cantelli, Steffens, Steffens, \& Carrão-Panizzi, 2018; Tres, Steffens, \& Steffens, 2019; Yang, Jiang, \& Li, 2021).

Soybean, the main ingredient of tofu, is one of the most widely cultivated crops globally, which is also well accepted as a functional food (Dahmer et al., 2020; Rigo, Dahmer, Steffens, Steffens, \& Carrão-Panizzi, 2015). However, the use of conventional soybean cultivars is limited by the bitter, rancid and astringent taste (raw bean or beany flavor). These characteristics are due to the action of lipoxygenases, enzymes that catalyze the addition of molecular oxygen to the pentadiene system of polyunsaturated fatty acids, forming hydroperoxides of the corresponding fatty acids. However, although, these enzymes can be inactivated by heat treatment near $100{ }^{\circ} \mathrm{C}$ for 5 to $10 \mathrm{~min}$ (Stanojevic, Barać, Pešić, \& Vucelic-Radovic, 2020), soybean cultivars, genetic developed for free lipoxygenases and smoother flavor will have characteristics more suitable for human consumption. At Embrapa, soybean genetic improvement for human consumption has developed cultivars that could increase soybean consumption, by stimulating the development of soy-based products with better characteristics (Cantelli et al., 2017; Dahmer, Rigo, Steffens, Steffens, \& Carrão-Panizzi, 2018; Schmidt, Cantelli, Steffens, Steffens, \& Zeni, 2017). Therefore, quality of tofu may be affected by soybean varieties, chemical components and biologically active compounds (Stanojevic, Barac, Pesic, \& Vucelic-Radovic, 2011).

Traditionally, tofu consists of a gel developed from soy extract, which presents the first step the proteins denaturation by heat. According to the method used, type of coagulant and moisture content, it can be called firm, soft and silken. Other parameters such as yield and product quality are influenced by the type of soybean cultivar, grain quality (which depends on plant growing and storage conditions) and tofu processing conditions (Yin et al., 2020).

Tofu is prepared by coagulating soymilk according the gelling ability of soybean protein. The type of coagulant is very important in the tofu process, which determines the gelling behavior and the formation of aggregated soybean protein (Yang, Jiang, et al., 2021; Yang, Wang, et al., 2021). Various coagulants can be applied in the coagulation of soymilk (Cao et al., 2017; Jun et al., 2019). Commercially, the $\mathrm{MgCl}_{2}$ is one of the most used in industry, presents fast coagulation ability, 
generating product with coarse, hard, granular texture. New coagulants have been studied by researchers and industry to meet consumer requirements for tofu production that can promote peculiar technological characteristics as texture, flavor, acceptability (Jun et al., 2019; Shen \& Kuo, 2017).

A new coagulant the flower of C. cardunculus L., also known as cardoon or thistle flower, which was not yet described in the literature for coagulating soymilk, is normally, used to obtain a buttery sheep's milk cheese, with different sensory characteristics due to its greater proteolytic capacity widely and well consumers acceptance (Faion et al., 2020).

In this study, cardoon flower was investigated as a novel tofu coagulant. Thus, the aim of the present study was to develop tofu from BRS 267, the special soybean cultivar, coagulated with cardoon flower in comparison with traditional coagulant $\left(\mathrm{MgCl}_{2}\right)$. It was also evaluated its impacts on tofu and product properties including yield, appearance, color, texture, syneresis, micro-structure, consumer preference and microbiology.

\section{Methodology}

\subsection{Soybean}

Soybean seed (Glycine max (L.) Merrill) of BRS 267 cultivar was provided by Brazilian Agricultural Research Corporation (Embrapa) - National Wheat Research Center, from Passo Fundo, Brazil.

\subsection{Soymilk}

Soymilk was produced from the hulled beans according to previously reported process by Scherer et al. (2021). Soybeans $(150 \mathrm{~g})$ were washed and then soaked in water $(500 \mathrm{~mL})$ for $16 \mathrm{~h}\left(\sim 22^{\circ} \mathrm{C}\right)$. The soaked soybean grains were mixed with distilled water at $90{ }^{\circ} \mathrm{C}$, in weight ratio of $1: 8$ before blending. To obtain the soymilk, the mixture was blended (Blender M. Vitrory, model HP 12, Brazil) for 3 min at medium-high speed. The soymilk slurry was filtered through vacuum (model TE-058, Tecnal, Brazil) with cloth 100-mesh screen. The filtrate (soymilk) was characterized in relation to total protein, antioxidant activity and $\mathrm{pH}$.

\subsection{Cardoon flower coagulant extract}

The cardoon flower samples were obtained from the Viana do Castelo herb (Portugal). The vegetable coagulant was prepared by using $3.5 \mathrm{~g}$ cardoon flower and $25 \mathrm{~g}$ of salt $(\mathrm{NaCl})$, which were macerated with grit and pistil. The extract was evaluated in relation to protease activity by azocasein hydrolysis according to Charney \& Tomarelli (1947), and $\mathrm{pH}$, antioxidant activity and Kunitz Trypsin Inhibitor (KTI).

\subsection{Tofu production}

Tofu was made with the soybean cultivar BRS 267 using the methodology adapted from Benassi, Benassi, \& Prudencio (2011) using cardoon flower extract and $\mathrm{MgCl}_{2}$ (standard formulation) as coagulants.

Briefly, $2 \mathrm{~L}$ of soymilk was heat at $90{ }^{\circ} \mathrm{C}$ in a covered container, under direct fire, followed by another $10 \mathrm{~min}$ in a water bath. After heating, the soymilk was cooled and the coagulants were added under vigorous stirring. Soymilk (2L) was incubated at $30{ }^{\circ} \mathrm{C}$ for 60 min with $5 \mathrm{~g}$ extract cardoon flower diluted in distilled water. For $\mathrm{MgCl}_{2}(3 \mathrm{~g}$ in $40 \mathrm{~mL}$ warm water $)$ was diluted in $760 \mathrm{~mL}$ of soymilk; coagulation temperature of $70{ }^{\circ} \mathrm{C}$ of $20 \mathrm{~min}$. After coagulation, the curd was cut and drained for $30 \mathrm{~min}$. Afterwards, the tofu's were conditioned at a temperature of $4{ }^{\circ} \mathrm{C}$ and stored for 14 days. All samples were prepared in triplicate. 


\subsection{Physical, chemical and morphological analyses}

The tofu samples were characterized in relation to moisture, $\mathrm{pH}$, total minerals, lipids, protein, color $\left(\mathrm{L}^{*}, \mathrm{a}^{*}, \mathrm{~b}^{*}, \mathrm{C}^{*}\right.$ and $\left.{ }^{\circ} \mathrm{Hue}\right)$, KTI, ureatic activity index, phytic acid, acidity, syneresis, and texture profile during the $1^{\text {st }}, 7^{\text {th }}$ and $14^{\text {th }}$ days of storage. Yield, antioxidant activity and morphology were evaluated on the first day.

Yield was calculated according to Benassi et al. (2011), using Equation 1. The results were expressed on a wet basis.

$$
\text { Yield }(\%)=\frac{\text { Weight of tofu }}{\text { Weight of soybeans }}+\frac{\text { Weight of soymilk }}{\text { Weight of soybeans }} x 100
$$

The syneresis was determined by the method of drainage (Hassan, Frank, Schmidt, \& Shalabi, 1996). The volume of whey collected during $4 \mathrm{~h}$ at $4^{\circ} \mathrm{C}$ was quantified and dividing by the sample weight and multiplying by 100 . The syneresis index was expressed in \%, on a wet basis.

The moisture was determined in an air recirculating oven at $105^{\circ} \mathrm{C}$ for $4 \mathrm{~h}(\mathrm{AOAC}, 2011)$. The $\mathrm{pH}$ measurements were carried out in the proportion of $1 / 10(\mathrm{v} / \mathrm{v})$ in a $\mathrm{pH}$ meter (Digimed, model DM-22, Germany). Total minerals was obtained by a gravimetric method, after calcination at $550^{\circ} \mathrm{C}$ for $6 \mathrm{~h}$ (IAL, 2008). The lipid content was performed by Soxhlet method (IAL, 2008). The total nitrogen was obtained by Kjeldahl method (IAL, 2008) and multiplied by a factor of 6.25 to obtain the protein.

The determination of the color (for each sample the average of three replicates, in different regions) was performed in a colorimeter (Minolta Chroma Meter, model CR-400, Japan). The following parameters were used: $\mathrm{L}^{*}$ (lightness), $\mathrm{a}^{*+}$ (a tendency to be more red) and $\mathrm{b}^{*}+$ (a tendency to be more yellow).

The chromatic $\left(\mathrm{C}^{*}\right)$ was calculated using the values obtained directly from the colorimeter (McGuire, 1992), according to Equation 2.

$$
\mathrm{c}^{*}=\left(\mathrm{a}^{*^{2}}+\mathrm{b}^{* 2}\right)^{1 / 2}
$$

The Hue color angle was obtained by Equation 3 (McGuire, 1992).

\section{Hue=arctan $\left(b^{*} / a^{*}\right)$}

KTI was determined according to Hamerstrand, Black, \& Glover (1981). This method is based on the trypsin inhibition degree, and the benzoyl-DL-arginine p-nitroanilide hydrochloride substrate (BAPA) hydrolysis.

Urease activity was determined according to AOAC (2005), where $0.2 \mathrm{~g}$ of sample was incubated in $10 \mathrm{~mL}$ of phosphate buffered urea solution at $30^{\circ} \mathrm{C}$ for $30 \mathrm{~min}$.

Phytic acid was determined spectrophotometry according to Ellis \& Morris (1986).

Titratable acidity was determined in Dornic degrees according to IAL (2008).

To determine the antioxidant activity of tofu, cardoon flower extract, and soymilk, the samples were freezing (ultrafreezer CL 600-80, Japan) at $-80{ }^{\circ} \mathrm{C}$ for $24 \mathrm{~h}$. Subsequently, they were lyophilized (Liotop L101AISI304, England) for 24 h. The free radical scavenging activity was evaluated using the 1,1-diphenyl-2-picrylhydrazil (DPPH) (Sigma Aldrich, Germany) according to Miranda \& Fraga (2006), with modifications. The reaction consisted of $500 \mu \mathrm{L}$ of $0.1 \mathrm{mM}$ DPPH 
ethanolic solution with $500 \mu \mathrm{L}$ extract containing decreasing concentrations $(10-0.1 \mathrm{mg} / \mathrm{mL})$. The control solution was prepared with $500 \mu \mathrm{L}$ DPPH and $500 \mu \mathrm{L}$ ethanol. In the white solution, only the ethanol solvent (without sample and DPPH) was used. After $30 \mathrm{~min}$ at room temperature (protected from light), the absorbance values were measured at $515 \mathrm{~nm}$. The uptake percentage of the DPPH radical was obtained in terms of the percentage of antioxidant activity (AA\%). After evaluating the ideal concentration range, was calculated the inhibitory concentration $\left(\mathrm{IC}_{50}\right)$ of the extract needed to inhibit $50 \%$ of the DPPH radicals obtained from the linear regression curve (Silvestri et al., 2010).

The instrumental evaluation of texture profiles was performed using a texturometer (CT3, Brookfield, France). A cylindrical stainless-steel probe of $35 \mathrm{~mm}$ diameter, pretest speed $1 \mathrm{~mm} / \mathrm{s}$, test speed of $2 \mathrm{~mm} / \mathrm{s}$, post-test speed of $2 \mathrm{~mm} / \mathrm{s}$, with $25.4 \mathrm{~mm}$ diameter cylindrical acrylic probe. The texture properties obtained were hardness (N), stickiness, (N) springiness $(\mathrm{mm})$, and cohesiveness. For each sample, at least ten determinations were obtained.

The morphological images were obtained by scanning electronic microscopy (SEM) Zeiss (model EVO LS25, Germany) at operating voltage $10 \mathrm{kV}$ using. The dehydrated samples were previously covered with a gold layer with a metallizer (Sputter Coater SCD 050 - Balzers).

\subsection{Microbiological analysis}

Microbiology analyses of tofu samples consisted in determining Most Probable Number (MPN) of coliforms at $45{ }^{\circ} \mathrm{C}$, Staphylococcus coagulase positive, Salmonella sp., were performed according to the recommendation and requirements of the IN 60/2019 (Brasil, 2019a). Counting of Bacillus cereus was performed on selective agar for cereus (Acumedia).

\subsection{Sensory analysis}

The sensory evaluation of the tofu samples was carried out using a consumer acceptance test - a structured 9-point hedonic scale $(9=$ like it a lot and $1=$ dislike a lot) (Queiroz \& Treptow, 2006). The tests were performed with the aid of 60 untrained panelists. Each panelist received 4 samples of each tofu distributed in containers and encoded with three random digits, accompanied by water. The tofu attributes evaluated were global acceptance and purchase intention. The experiment was approved by the Research Ethics Committee (URI-Erechim) and registered at the Platform Brazil, CAAE number 12952719.3.0000.5351.

\subsection{Statistical analysis}

The results $(n=3)$ were statistically treated by analysis of variance (ANOVA), followed by the averages differences comparison by the Tukey and Student test, using the Statistic v. 5.0 software, with a 95\% confidence level. In addition, the Pearson correlation analysis and principal component analysis (PCA) were performed using XLSTAT software (free version).

\section{Results and Discussion}

\subsection{Physical, chemical and structural properties}

Moisture presented values ranging from 80.23 to $86.4 \mathrm{~g} / 100 \mathrm{~g}$ (Table 1), with significant differences between samples $(\mathrm{p}<0.05)$ on the first day of storage. The tofu coagulated with cardoon flower showed greater water retention capacity, which can be due to the low cross-linking between the protein molecules resulting in a softer product. The low crosslinking provides a soft mass, allowing air gaps within the network (Jayasena, Tah, \& Nasar-Abbas, 2014). However, considering the storage days, it is observed that the moisture content decreased for all tofu samples evaluated. 
Research, Society and Development, v. 10, n. 16, e207101623576, 2021

The $\mathrm{pH}$ values (Table 1) differed significantly $(\mathrm{p}<0.05)$ between coagulants and storage. The $\mathrm{pH}$ of the coagulant extract (cardoon flower) was 5.13 and 6.45 of soymilk. The slightly acidic behavior of cardoon flower extract may be one of the factors that favors soymilk coagulation, resulting more acid tofu as compared to that obtained with traditional coagulant $\left(\mathrm{MgCl}_{2}\right)$. Faion et al. (2020) obtained sheep's milk cheeses with lower acidity ( $\left.\mathrm{pH} 5.53\right)$ showing that the flower extract provided a slight acidification in the cheese. It is also observed a reduction in $\mathrm{pH}$ and an increase in acidity for all tofu samples during the storage.

The values of total lipids, proteins and minerals (Table 1) decreased during storage, possibly due to the loss of liquid and exudation of proteins. This reduction in mineral content over storage time is due to the release of whey during storage, causing salt migration from tofu to whey (Schmidt et al., 2017).

Color influence on the acceptability of the product. The tofu coagulated with cardoon flower extract was lighter $\left(\mathrm{L}^{*}\right)$ compared to the traditional (F2) (Table 1 and Fig. 1). Durign the storage, a slight reduction in the intensity of luminosity L* and chromaticity was observed $\left(b^{*}\right)$ for all tofu samples $(\mathrm{p}<0.05)$. Tofu can be generically designated as white products (Benassi, Várea, \& Prudencio, 2012). Tofu with a white color is considered the best, as it is a quality factor for this product (Evans, Tsukamoto, \& Nielsen, 1997). Redness a* presented a slight decrease with the storage in the traditional tofu (coagulated with $\mathrm{MgCl}_{2}$ ), on the other hand an opposite behavior was observed for the tofu coagulated with cardoon flower. Hue* differed between coagulants $(\mathrm{p}<0.05)$, and during storage no differences were observed $(\mathrm{p}>0.05)$. $\mathrm{C}^{*}$ differed between coagulants, and during storage $(\mathrm{p}<0.05)$. 
Research, Society and Development, v. 10, n. 16, e207101623576, 2021

(CC BY 4.0) | ISSN 2525-3409 | DOI: http://dx.doi.org/10.33448/rsd-v10i16.23576

Table 1 - Physical and chemical characteristics of tofu elaborated with soybean cultivar BRS 267 coagulated with cardoon flower (F1) and $\mathrm{MgCl}_{2}(\mathrm{~F} 2)$ during storage $\left(1^{\text {st }}, 7^{\text {th }}\right.$ and $14^{\text {th }}$ days).

\begin{tabular}{|c|c|c|c|c|}
\hline \multicolumn{2}{|c|}{ Analysis } & Storage time & $\begin{array}{c}\text { Coagulated with cardoon } \\
\text { flower (F1) }\end{array}$ & Coagulated with $\mathrm{MgCl}_{2}(\mathrm{~F} 2)$ \\
\hline \multirow{3}{*}{\multicolumn{2}{|c|}{$\begin{array}{l}\text { Moisture } \\
(\mathrm{g} / 100 \mathrm{~g})\end{array}$}} & 1 & $86.40^{\mathrm{aA}} \pm 0.10$ & $80.23^{\mathrm{bA}} \pm 0.03$ \\
\hline & & 7 & $85.91^{\mathrm{aB}} \pm 0.03$ & $79.90^{\mathrm{bB}} \pm 0.10$ \\
\hline & & 14 & $83.37^{\mathrm{aC}} \pm 0.15$ & $79.70^{\mathrm{bB}} \pm 0.10$ \\
\hline \multirow{3}{*}{\multicolumn{2}{|c|}{$\mathrm{pH}$}} & 1 & $5.36^{\mathrm{bA}} \pm 0.03$ & $5.45^{\mathrm{aA}} \pm 0.03$ \\
\hline & & 7 & $5.29^{\mathrm{bB}} \pm 0.01$ & $5.36^{\mathrm{aB}} \pm 0.03$ \\
\hline & & 14 & $5.24^{\mathrm{bC}} \pm 0.01$ & $5.30^{\mathrm{aC}} \pm 0.01$ \\
\hline \multirow{3}{*}{\multicolumn{2}{|c|}{$\begin{array}{l}\text { Total minerals } \\
(\mathrm{g} / 100 \mathrm{~g})\end{array}$}} & 1 & $0.75^{\mathrm{bA}} \pm 0.03$ & $0.85^{\mathrm{aA}} \pm 0.02$ \\
\hline & & 7 & $0.70^{\mathrm{bAB}} \pm 0.03$ & $0.81^{\mathrm{aAB}} \pm 0.02$ \\
\hline & & 14 & $0.69^{\mathrm{bB}} \pm 0.01$ & $0.79^{\mathrm{aB}} \pm 0.01$ \\
\hline \multirow{3}{*}{\multicolumn{2}{|c|}{ Total lipids (g/100 g) }} & 1 & $3.93^{\mathrm{aA}} \pm 0.04$ & $3.85^{\mathrm{bA}} \pm 0.03$ \\
\hline & & 7 & $3.85^{\mathrm{aA}} \pm 0.05$ & $3.80^{\mathrm{aAB}} \pm 0.04$ \\
\hline & & 14 & $3.80^{\mathrm{aB}} \pm 0.02$ & $3.73^{\mathrm{bB}} \pm 0.03$ \\
\hline \multirow{3}{*}{\multicolumn{2}{|c|}{ Total proteins $(\mathrm{g} / 100 \mathrm{~g})$}} & 1 & $12.45^{\mathrm{aA}} \pm 0.03$ & $11.36^{\mathrm{bA}} \pm 0.03$ \\
\hline & & 7 & $12.15^{\mathrm{aB}} \pm 0.02$ & $11.34^{\mathrm{bA}} \pm 0.02$ \\
\hline & & 14 & $11.64^{\mathrm{aC}} \pm 0.04$ & $11.23^{\mathrm{bB}} \pm 0.01$ \\
\hline \multirow{15}{*}{ Color } & $\mathrm{L}^{*}$ & & $79.65^{\mathrm{aA}} \pm 0.34$ & $78.58^{\mathrm{bA}} \pm 0.16$ \\
\hline & $\mathrm{a}^{*}$ & & $0.58^{\mathrm{aC}} \pm 0.02$ & $0.22^{\mathrm{bA}} \pm 0.04$ \\
\hline & $b^{*}$ & 1 & $12.60^{\mathrm{bA}} \pm 0.03$ & $12.75^{\mathrm{aA}} \pm 0.09$ \\
\hline & ${ }^{\circ} \mathrm{Hue}$ & & $1.52^{\mathrm{aA}} \pm 0.03$ & $1.55^{\mathrm{aA}} \pm 0.01$ \\
\hline & $\mathrm{C}^{*}$ & & $12.62^{\mathrm{bA}} \pm 0.30$ & $12.75^{\mathrm{aA}} \pm 0.10$ \\
\hline & $\mathrm{L}^{*}$ & & $79.24^{\mathrm{aA}} \pm 0.12$ & $77.61^{\mathrm{bB}} \pm 0.02$ \\
\hline & $a^{*}$ & & $0.66^{\mathrm{aB}} \pm 0.05$ & $0.16^{\mathrm{bB}} \pm 0.12$ \\
\hline & $b^{*}$ & 7 & $12.08^{\mathrm{bB}} \pm 0.09$ & $12.38^{\mathrm{aB}} \pm 0.16$ \\
\hline & ${ }^{\mathrm{o}} \mathrm{Hue}$ & & $1.52^{\mathrm{bA}} \pm 0.01$ & $1.56^{\mathrm{aA}} \pm 0.01$ \\
\hline & $\mathrm{C}^{*}$ & & $12.10^{\mathrm{bB}} \pm 0.10$ & $12.39^{\mathrm{aB}} \pm 0.10$ \\
\hline & $\mathrm{L}^{*}$ & & $78.30^{\mathrm{aB}} \pm 0.05$ & $77.18^{\mathrm{bC}} \pm 0.04$ \\
\hline & $\mathrm{a}^{*}$ & & $0.72^{\mathrm{aA}} \pm 0.03$ & $0.12^{\mathrm{bC}} \pm 0.03$ \\
\hline & $\mathrm{b}^{*}$ & 14 & $11.12^{\mathrm{bC}} \pm 0.09$ & $12.14^{\mathrm{aC}} \pm 0.12$ \\
\hline & ${ }^{\circ} \mathrm{Hue}$ & & $1.51^{\mathrm{bA}} \pm 0.01$ & $1.56^{\mathrm{aA}} \pm 0.01$ \\
\hline & $\mathrm{C}^{*}$ & & $11.14^{\mathrm{bC}} \pm 0.01$ & $12.14^{\mathrm{aC}} \pm 0.08$ \\
\hline \multirow{3}{*}{\multicolumn{2}{|c|}{ KTI (mg.IT/g) }} & 1 & $1.23^{\mathrm{aA}} \pm 0.03$ & $1.21^{\mathrm{bA}} \pm 0.02$ \\
\hline & & 7 & $1.21^{\mathrm{aA}} \pm 0.02$ & $1.21^{\mathrm{aA}} \pm 0.01$ \\
\hline & & 14 & $1.20^{\mathrm{aA}} \pm 0.01$ & $1.22^{\mathrm{aA}} \pm 0.01$ \\
\hline \multirow{3}{*}{\multicolumn{2}{|c|}{ Ureactic activity $(\mathrm{pH})$}} & 1 & $0.08^{\mathrm{aA}} \pm 0.01$ & $0.09^{\mathrm{aA}} \pm 0.01$ \\
\hline & & 7 & $0.07^{\mathrm{aA}} \pm 0.02$ & $0.08^{\mathrm{aA}} \pm 0.01$ \\
\hline & & 14 & $0.06^{\mathrm{aA}} \pm 0.01$ & $0.08^{\mathrm{aA}} \pm 0.01$ \\
\hline \multirow{3}{*}{\multicolumn{2}{|c|}{ Phytic acid (g/100 g) }} & 1 & $1.81^{\mathrm{aA}} \pm 0.01$ & $1.75^{\mathrm{bA}} \pm 0.04$ \\
\hline & & 7 & $1.79^{\mathrm{aAB}} \pm 0.01$ & $1.74^{\mathrm{bA}} \pm 0.02$ \\
\hline & & 14 & $1.77^{\mathrm{aB}} \pm 0.01$ & $1.73^{\mathrm{aA}} \pm 0.01$ \\
\hline
\end{tabular}




\begin{tabular}{l|c|c|c}
\hline & 1 & $0.36^{\mathrm{aB}} \pm 0.04$ & $0.32^{\mathrm{bC}} \pm 0.01$ \\
Acidity (\% lactic acid) & 7 & $0.96^{\mathrm{aA}} \pm 0.05$ & $0.67^{\mathrm{bB}} \pm 0.02$ \\
& 14 & $0.98^{\mathrm{bA}} \pm 0.01$ & $1.13^{\mathrm{aA}} \pm 0.01$ \\
\hline Yield (g tofu & 1 & $216.43^{\mathrm{a}} \pm 3.21$ & $157.34^{\mathrm{b}} \pm 2.07$ \\
\hline /100 g seeds) & 1 & $24.33^{\mathrm{aA}} \pm 0.6$ & $5.5^{\mathrm{bA}} \pm 0.5$ \\
Syneresis (\%) & 7 & $4.73^{\mathrm{aB}} \pm 0.64$ & $1.26^{\mathrm{bB}} \pm 0.05$ \\
& 14 & $1.89^{\mathrm{aC}} \pm 0.01$ & $0.92^{\mathrm{bC}} \pm 0.03$ \\
\hline
\end{tabular}

*Means ( \pm Standard Deviation) followed by equal letters lowercase/uppercase indicate that there is no significant difference at the 5\% level (Student's t-test and Tukey test) in the row/column, respectively. Source: Authors.

Kunitz Trypsin Inhibitor (KTI), ureatic activity index and phytic acid, are the antinutritional factors, that must be reduced or inactivated ( $\mathrm{Gu}$ et al., 2017). There was a reduction of $93 \%$ in KTI value in the tofu compared to soymilk, indicating that the process contributed to obtaining a healthier product. All tofu samples showed minimum residual levels of KTI (Table 1), which is accepted for human consumption, and is within the reduction of up to $80 \%$ in inhibitor (Dahmer et al., 2018). Ureatic activity index values are in the range considered for inactivation of the enzyme (0.05 to $0.3 \mathrm{pH}$ unit) (Olguin et al., 2003). The low phytic acid values found are interesting, as they can provide certain functional action (Kumar et al., 2005).

All samples showed loss of liquid during storage $(\mathrm{p}<0.05)$, where tofu coagulated with cardoon flower showed high whey release. This could be due to the protease activity present in the cardoon flower extract $(1,12)$ which causes weak network connections. In general, the activity of cardosines obtained from $C$. cardunculus present activity at $\mathrm{pH}$ ranging between 2 and 7, with the maximum activity at pH 5 (Campos, Guerra, Aguilar, Ventura, \& Camacho, 1990), which also corroborates the $\mathrm{pH}$ of tofu.

Tofu coagulated with cardoon flower showed the high yield $(\mathrm{p}<0.05)$ (Table 1), which could bind larger amounts of water. Also, the high yield resulted from the high content of total protein in tofu. The coagulation with protease from cardoon flower improves the absorption of water inside the fiber-protein matrices of the soy. The high yield is related to high moisture content, that is correlated to more uniform gel (Fig. 1a) and high-water absorption capacity, denser and steadier network. On the other hand, the tofu coagulated with $\mathrm{MgCl}_{2}$ showed a firm appearance (Fig. 1b). Homogeneous tofu gel with compact structure present low degree of syneresis (Khoder et al., 2020).

These differences are related to coagulation mechanisms of the two coagulant. In the case of $\mathrm{MgCl}_{2}$ has bivalent cations in the salt, that is release after combination with deprotonated phosphate group in soymilk, decreasing the $\mathrm{pH}$ by liberation of chloride anions (Joo \& Cavender, 2020). In this study, cardoon flower extract was investigated as a novel tofu coagulant. The extract has a set of cardenosins A and B enzymes, namely aspartic proteases. The use of cardoon flower as coagulant, hydrolyze enzymatic the soy protein modifying the structure (Fig. 1c), and hidden hydrophobic groups become involved, which result in aggregate formation (form gel networks). Enzymatic hydrolysis by proteases occur by exposure of hydrophobic areas and increased molecular flexibility of polypeptides resulting in an increase of the adsorption rate (Miñones Conde \& Rodríguez Patino, 2007).

Changes in tofu microstructure may be related to the type of coagulant used ( $\mathrm{Li}$ et al., 2021). The tofu coagulated with cardoon flower extract showed a certain discontinuity in the protein matrix structure with some fragments and large pores or cavities, which were possibly formed by the high-water retention capacity. This characteristic is also related to yield, moisture (Table 1) and texture profile (Table 2). 
Research, Society and Development, v. 10, n. 16, e207101623576, 2021

(CC BY 4.0) | ISSN 2525-3409 | DOI: http://dx.doi.org/10.33448/rsd-v10i16.23576

Figure 1 - Appearances and microstructure of tofu coagulated with cardoon flower (a) and $\mathrm{MgCl}_{2}(\mathrm{~b})$.

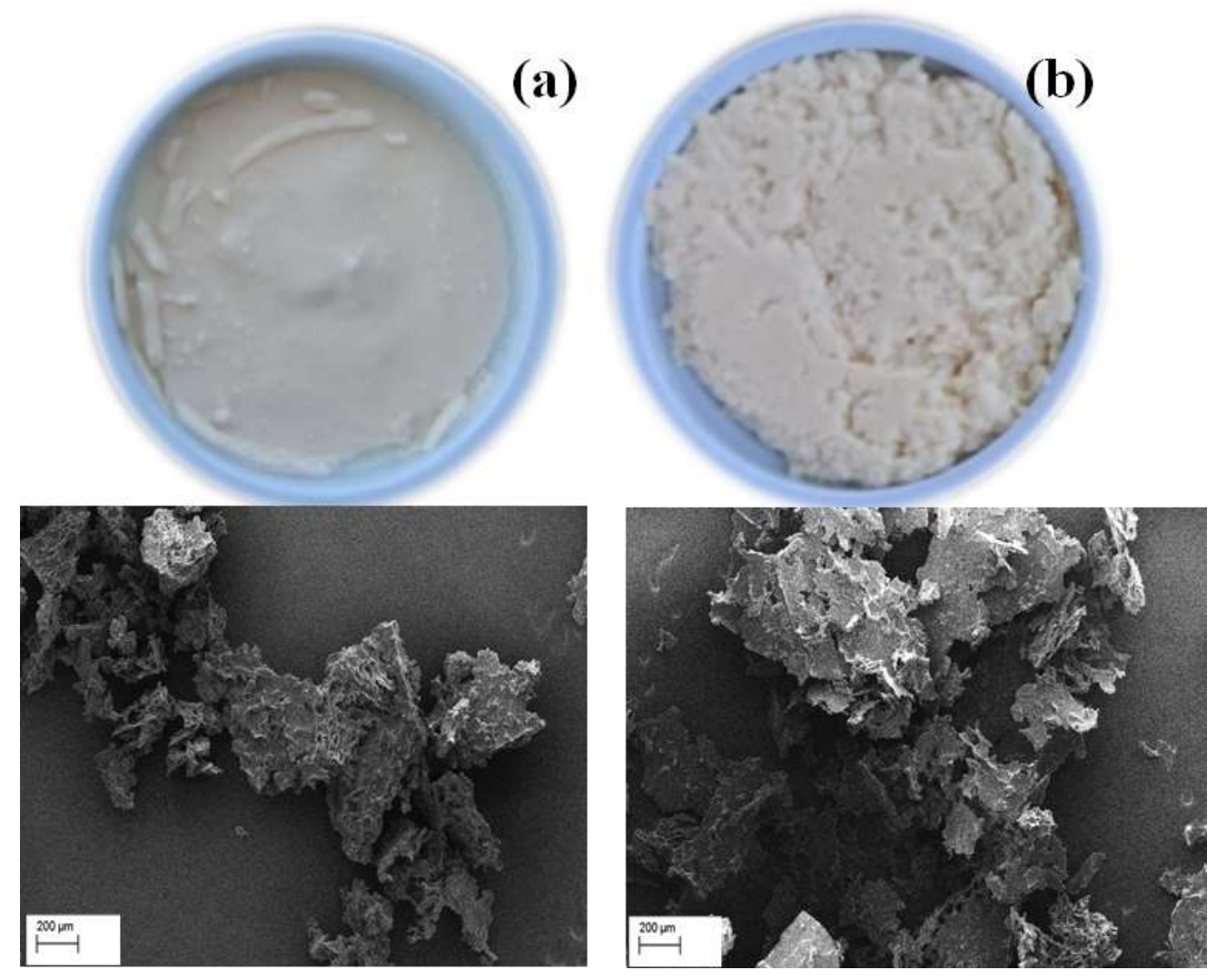

Source: Authors.

\subsection{Texture profile analysis}

The hardness of tofu F2 was $10.90 \mathrm{~N}$ (Table 2), which is related to coagulant used $\mathrm{MgCl}_{2}$. On the other hand, the tofu coagulated with cardoon flower showed lower hardness meaning that it needs less force to break through the structure initially (Joo \& Cavender, 2020) due the more retained moisture. It was also possible to verify that all tofu samples showed a tendency to increase the hardness during the storage (Table 2), which may be related to the decrease in moisture (Table 1).

It is observed that the tofu coagulated with cardoon flower had low stickiness, which was increased during storage $(\mathrm{p}<0.05)$. Stickiness can be defined as the product of hardness and cohesiveness, which refers to the energy required to disintegrate semi-solid foods before being swallowed (Yuan \& Chang, 2007). Thus, tofu developed with $\mathrm{MgCl}_{2}$ require more energy in chewing, as they were more complete and more resistant to breakage.

The springiness of tofu showed significant difference $(\mathrm{p}<0,05)$ between the coagulants. When springiness is analyzed in terms of compression, it represents the perception of the rubbery gel in the mouth, where high values represent that the gel is broken into a few large pieces, and low values come from breaking into many and small pieces (Foegeding \& Drake, 2007). Thus, the tofu coagulated with $\mathrm{MgCl}_{2}$ showed great springiness. 
Table 2 - Textural properties (hardness, stickiness, springiness and cohesiveness) of tofu during the storage $\left(1^{\text {st }}, 7^{\text {th }}\right.$ and $14^{\text {th }}$ days).

\begin{tabular}{|c|c|c|c|}
\hline Texture & Storage time & $\begin{array}{c}\text { Coagulated with cardoon flower } \\
\text { (F1) }\end{array}$ & $\begin{array}{c}\text { Coagulated with } \mathrm{MgCl}_{2} \\
\text { (F2) }\end{array}$ \\
\hline \multirow{3}{*}{ Hardness (N) } & 1 & $0.57^{\mathrm{bC}} \pm 0.06$ & $10.90^{\mathrm{aC}} \pm 0.05$ \\
\hline & 7 & $0.68^{\mathrm{bB}} \pm 0.01$ & $11.45^{\mathrm{aB}} \pm 0.07$ \\
\hline & 14 & $0.86^{\mathrm{bA}} \pm 0.02$ & $12.19^{\mathrm{aA}} \pm 0.01$ \\
\hline \multirow{3}{*}{ Stickiness (N) } & 1 & $0.38^{\mathrm{bB}} \pm 0.04$ & $3.79^{\mathrm{aB}} \pm 0.07$ \\
\hline & 7 & $0.41^{\mathrm{bB}} \pm 0.03$ & $3.88^{\mathrm{aB}} \pm 0.08$ \\
\hline & 14 & $0.51^{\mathrm{bA}} \pm 0.04$ & $4.12^{\mathrm{aA}} \pm 0.07$ \\
\hline \multirow{3}{*}{ Springiness $(\mathrm{mm})$} & 1 & $8.17^{\mathrm{bA}} \pm 0.09$ & $8.82^{\mathrm{aA}} \pm 0.09$ \\
\hline & 7 & $7.81^{\mathrm{bB}} \pm 0.05$ & $8.66^{\mathrm{aAB}} \pm 0.07$ \\
\hline & 14 & $7.77^{\mathrm{bB}} \pm 0.06$ & $8.56^{\mathrm{aB}} \pm 0.06$ \\
\hline \multirow{3}{*}{ Cohesiveness } & 1 & $0.56^{\mathrm{aA}} \pm 0.08$ & $0.57^{\mathrm{aA}} \pm 0.02$ \\
\hline & 7 & $0.54^{\mathrm{aAB}} \pm 0.01$ & $0.55^{\mathrm{aA}} \pm 0.01$ \\
\hline & 14 & $0.48^{\mathrm{bB}} \pm 0.04$ & $0.51^{\mathrm{aB}} \pm 0.01$ \\
\hline
\end{tabular}

*Means ( \pm Standard Deviation) followed by equal letters lowercase/uppercase indicate that there is no significant difference at the 5\% level (Student's t-test and Tukey test) in the row/column, respectively. Source: Authors.

The results for cohesiveness decreasing during storage $(\mathrm{p}<0.05)$. These results suggest a stronger internal structure. Cohesion is defined as the work required to overcome the intrinsic bond of the material (Yuan \& Chang, 2007). The reason of lower cohesiveness and springiness of tofu coagulated with cardoon flower could be because the high moisture and protein content resulting in a decreasing protein-protein interactions (Ullah et al., 2019).

\subsection{Microbiological analysis of tofu}

Microbiological analyzes of coliforms at $45^{\circ} \mathrm{C}$ showed values lower than $1.5 \times 10^{1} \mathrm{MPN} / \mathrm{g}$, Staphylococcus coagulase positive (CFU/g), Salmonella sp. (25 g) and B. cereus $(\mathrm{CFU} / \mathrm{g})$ were not detected in the tofu samples until the $14^{\text {th }}$ day of storage. These results meet the standards required by current Brazilian legislation (Brasil, 2019b), indicating that the products were safe for human consumption.

\subsection{Sensory evaluation of tofu}

The sensory evaluation of tofu samples (F1 and F2) indicating high acceptability for the tofu coagulated with cardoon flower (5.52) in relation to traditional formulation (coagulated with $\mathrm{MgCl}_{2}$ ) (4.90), corresponding to the scale "moderately liked/liked very much", what was also observed in the purchase intention, 3.95 and 3.45, respectively.

\subsection{Antioxidant activity}

As the tofu coagulated with cardoon flower showed great acceptability and purchase intent, the antioxidant activity was evaluated in this product, and also in the flower extract and soymilk. The antioxidant activity was expressed as $\mathrm{IC}_{50}$, which is the amount of antioxidant needed to quantify the initial concentration of DPPH at 50\% (Brand-Williams, Cuvelier, \& Berset, 1995), this means that the lower the $\mathrm{IC}_{50}$ value, the greater the antioxidant activity. 
The $\mathrm{IC}_{50}$ value obtained for cardoon flower extract was $0.31 \pm 0.01 \mathrm{mg} / \mathrm{mL}$, for soymilk $0.41 \pm 0.3 \mathrm{~g} / \mathrm{mL}$ and for tofu $0.10 \pm 0.01 \mathrm{mg} / \mathrm{mL}$. Tofu has a greater antioxidant potential than cardoon flower and soymilk. As the cardoon flower is an vegetable coagulant has phenolic compounds that give it antioxidant activity (Gominho, Curt, Lourenço, Fernández, \& Pereira, 2018), associated with soy proteins which are rich phenolic compounds, contributed to this high activity in tofu. This property in tofu is interesting for formation of stable phenoxyl radical, and flavonoids have potent antioxidant activities by scavenging hydroxyl radicals (Poysa \& Woodrow, 2002).

\subsection{Main components (PCA) and correlation analysis}

Figure 2 presents the principal component analysis (PCA) for the physical, chemical, texture and sensory variables of the tofu during the storage. In PCA the variables are represented as vectors, which characterize the samples that are located close to them. The longer the vector, the better the explanation of variability between samples. The tofu samples are represented by triangles, each vertices being a repetition. The first (PC1) and second (PC2) dimension explained $84.37 \%$ of the total variance. The main component 1 (PC1) accounted $56.69 \%$, while main component 2 (PC2) was $27.68 \%$. It is observed that there was discrimination between tofu coagulated with cardoon flower $(\mathrm{F} 1)$ and $\mathrm{MgCl}_{2}(\mathrm{~F} 2)$. Tofu coagulated with $\mathrm{MgCl}_{2}$ (F2) showed great stickiness, hardness and springiness, ureatic activity and total mineral. Tofu coagulated with cardoon flower showed higher protein content, yield, $\mathrm{L}^{*}$, phytic acid, syneresis, total lipid and moisture, especially for the $1^{\text {st }}$ day of storage; yield, a* color and acceptability on the $7^{\text {th }}$; and acidity on the $14^{\text {th }}$ day.

The parameters observed in PCA (Fig. 2) confirm the relationship with values obtained through Pearson's correlation (Table 3). Moisture content was positively correlated ( $\mathrm{p}>0.05$ ) with protein, lipids, color ( $\mathrm{L}^{*}$ and $\mathrm{a}^{*}$ ), phytic acid, yield, syneresis and acceptance, that is, indicating that increasing the moisture content resulted in an increase in protein, yield, syneresis and acceptance. However, moisture was negatively correlated by texture parameters. Protein was positively correlated $(\mathrm{p}>0.05)$ by color $\left(\mathrm{L}^{*}, \mathrm{a}^{*}\right)$, phytic acid, yield, syneresis, and acceptance, which demonstrates that the higher the protein content in tofu, the higher was yield, syneresis and acceptance. Acceptance was positively correlated ( $<<0.05)$ with protein, yield, moisture and color $\mathrm{L}^{*}$ and $\mathrm{a}^{*}$. However, it was negatively correlated $(\mathrm{p}<0.05)$ with the texture parameters (hardness, stickiness, springiness, and cohesiveness), showing that when the texture characteristics were higher, the acceptance of the product was lower. 
Research, Society and Development, v. 10, n. 16, e207101623576, 2021

(CC BY 4.0) | ISSN 2525-3409 | DOI: http://dx.doi.org/10.33448/rsd-v10i16.23576

Figure 2 - Principal component analysis (PCA) of tofu coagulated with cardoon flower (F1) and $\mathrm{MgCl}_{2}(\mathrm{~F} 2)$ during the storage $\left(1^{\text {st }}, 7^{\text {th }}\right.$ and $14^{\text {th }}$ days $)$.

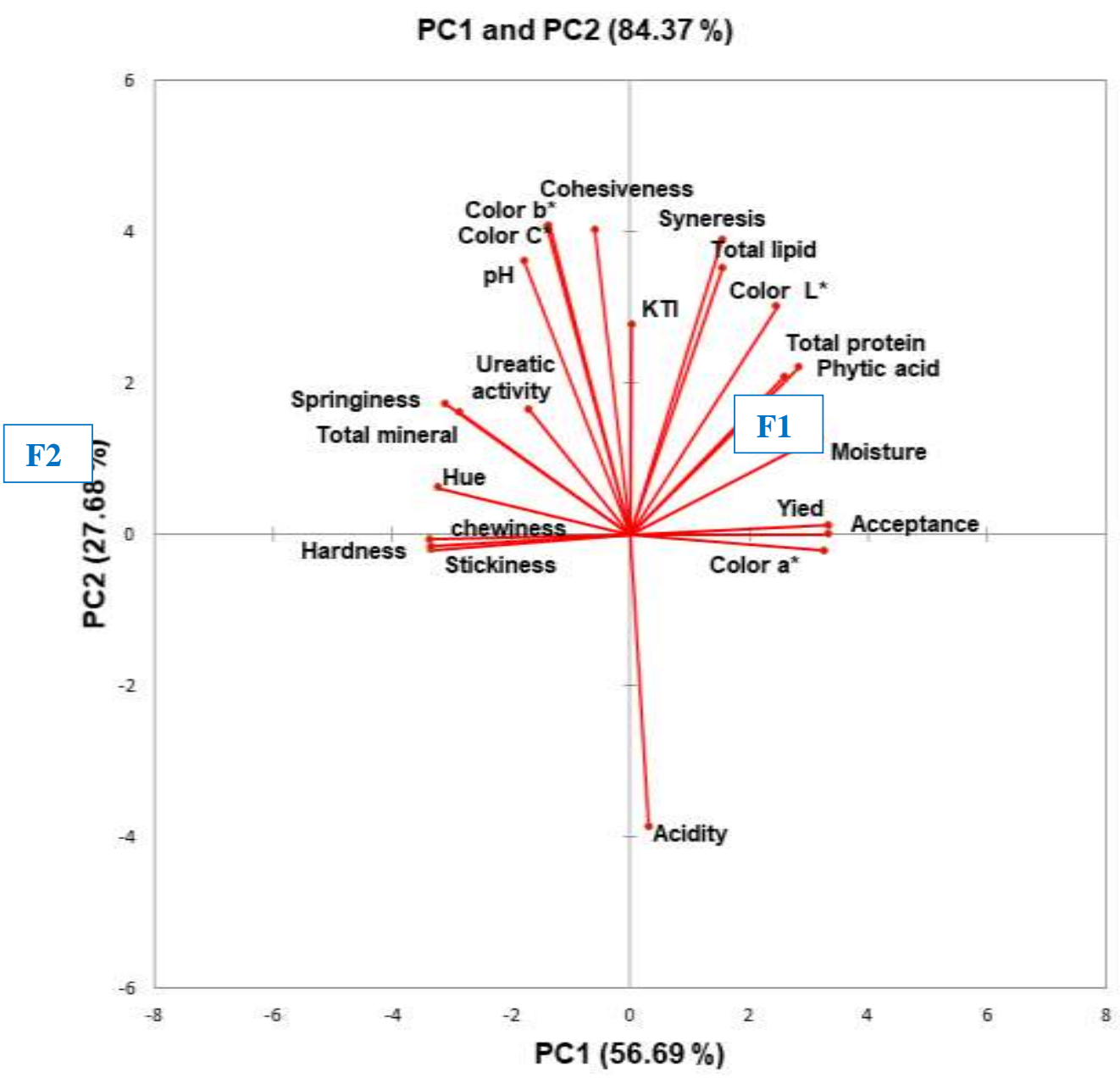

Source: Authors. 


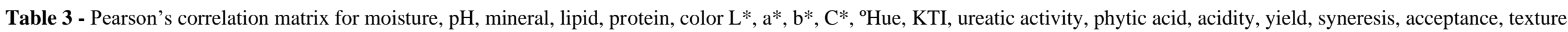
profile (hardness, stickiness, springiness, and cohesiveness) variables coagulated with cardoon flower $(\mathrm{F} 1)$ and $\mathrm{MgCl} 2(\mathrm{~F} 2)$ during the storage $\left(1^{\text {st }}, 7^{\text {th }}\right.$ and $14^{\text {th }}$ days).

\begin{tabular}{|c|c|c|c|c|c|c|c|c|c|c|c|c|c|c|c|c|c|c|c|c|c|}
\hline Variable & Moisture & $\mathrm{pH}$ & $\begin{array}{l}\text { Total } \\
\text { mineral }\end{array}$ & $\begin{array}{l}\text { Total } \\
\text { lipid }\end{array}$ & $\begin{array}{l}\text { Total } \\
\text { protein }\end{array}$ & $\mathrm{L}^{*}$ & $a^{*}$ & $b^{*}$ & Hue & $\mathrm{C}^{*}$ & KTI & $\begin{array}{l}\text { Ureatic } \\
\text { activity }\end{array}$ & $\begin{array}{l}\text { Phytic } \\
\text { acid }\end{array}$ & Acidity & Yied & $\begin{array}{l}\text { Syneres } \\
\text { is }\end{array}$ & $\begin{array}{l}\text { Accept } \\
\text { ance }\end{array}$ & Hardness & $\begin{array}{l}\text { Stickines } \\
\text { s }\end{array}$ & $\begin{array}{l}\text { Springi } \\
\text { ness }\end{array}$ & $\begin{array}{l}\text { Cohes } \\
\text { ivenes } \\
\mathrm{s}\end{array}$ \\
\hline Moisture & 1 & & & & & & & & & & & & & & & & & & & & \\
\hline pH & -0.324 & 1 & & & & & & & & & & & & & & & & & & & \\
\hline Total mineral & -0.719 & 0.615 & 1 & & & & & & & & & & & & & & & & & & \\
\hline Total lipid & 0.601 & 0.360 & -0.084 & 1 & & & & & & & & & & & & & & & & & \\
\hline Total protein & 0.969 & -0.153 & -0.563 & 0.693 & 1 & & & & & & & & & & & & & & & & \\
\hline Color L* & 0.866 & 0.139 & -0.440 & 0.831 & 0.900 & 1 & & & & & & & & & & & & & & & \\
\hline Color $\mathrm{a}^{*}$ & 0.869 & -0.505 & -0.862 & 0.458 & 0.748 & 0.694 & 1 & & & & & & & & & & & & & & \\
\hline Color b* & -0.135 & 0.802 & 0.613 & 0.456 & 0.064 & 0.210 & -0.442 & 1 & & & & & & & & & & & & & \\
\hline Hue & -0.828 & 0.552 & 0.877 & -0.392 & -0.690 & -0.633 & -0.996 & 0.515 & 1 & & & & & & & & & & & & \\
\hline Color $\mathrm{C}^{*}$ & -0.124 & 0.800 & 0.605 & 0.465 & 0.075 & 0.221 & -0.431 & 1.000 & 0.505 & 1 & & & & & & & & & & & \\
\hline KTI & 0.123 & 0.202 & 0.300 & 0.598 & 0.245 & 0.263 & 0.001 & 0.499 & 0.052 & 0.503 & 1 & & & & & & & & & & \\
\hline Ureatic activity & -0.326 & 0.653 & 0.361 & -0.105 & -0.196 & -0.108 & -0.545 & 0.455 & 0.570 & 0.450 & -0.211 & 1 & & & & & & & & & \\
\hline Phytic acid & 0.840 & -0.058 & -0.479 & 0.673 & 0.850 & 0.796 & 0.721 & 0.062 & -0.673 & 0.072 & 0.177 & -0.195 & 1 & & & & & & & & \\
\hline Acidity & -0.089 & -0.797 & -0.332 & -0.582 & -0.251 & -0.489 & 0.110 & -0.614 & -0.160 & -0.616 & -0.130 & -0.464 & -0.243 & 1 & & & & & & & \\
\hline Yied & 0.942 & -0.521 & -0.835 & 0.487 & 0.849 & 0.740 & 0.968 & -0.389 & -0.953 & -0.378 & 0.060 & -0.505 & 0.771 & 0.099 & 1 & & & & & & \\
\hline Syneresis & 0.657 & 0.257 & -0.130 & 0.714 & 0.794 & 0.754 & 0.347 & 0.386 & -0.279 & 0.393 & 0.397 & 0.136 & 0.666 & -0.628 & 0.474 & 1 & & & & & \\
\hline Acceptance & 0.944 & -0.530 & -0.846 & 0.453 & 0.848 & 0.733 & 0.962 & -0.413 & -0.949 & -0.402 & 0.000 & -0.485 & 0.763 & 0.094 & 0.997 & 0.474 & 1 & & & & \\
\hline Hardness & -0.950 & 0.480 & 0.833 & -0.489 & -0.860 & -0.769 & -0.964 & 0.382 & 0.949 & 0.371 & 0.006 & 0.462 & -0.778 & -0.034 & -0.994 & -0.494 & -0.997 & 1 & & & \\
\hline Stickiness & -0.952 & 0.489 & 0.833 & -0.477 & -0.862 & -0.763 & -0.958 & 0.389 & 0.944 & 0.379 & 0.017 & 0.457 & -0.776 & -0.041 & -0.993 & -0.494 & -0.998 & 1.000 & 1 & & \\
\hline Springiness & -0.792 & 0.764 & 0.898 & -0.125 & -0.630 & -0.460 & -0.901 & 0.662 & 0.915 & 0.653 & 0.221 & 0.574 & -0.577 & -0.412 & -0.911 & -0.139 & -0.923 & 0.905 & 0.910 & 1 & \\
\hline Cohesiveness & 0.028 & 0.687 & 0.434 & 0.686 & 0.192 & 0.401 & -0.184 & 0.753 & 0.250 & 0.755 & 0.657 & 0.212 & 0.182 & -0.547 & -0.136 & 0.353 & -0.179 & 0.145 & 0.155 & 0.446 & 1 \\
\hline
\end{tabular}

Note(s): Values in bold are different from 0 with a significance level alpha $=0.05(r>0.75)$. Source: Authors. 


\section{Final Considerations}

The properties of tofu including yield, syneresis, protein, creamy visual appearance, acceptability and purchase intention index were significantly improved using cardoon flower as coagulant. The results demonstrated that the extract from cardoon flower can be utilized as a coagulant in the production of tofu.

\section{Acknowledgments}

The authors would like to thank the National Council for Scientific and Technological Development (CNPq), the Coordination for the Improvement of Higher Education Personnel Brazil (CAPES) - Finance Code 001, the Fundação de Amparo à Pesquisa do Estado do Rio Grande do Sul (Fapergs), and the URI for the financial and structure support.

\section{References}

AOAC. Official Methods of Analysis of the Association of Official Analytical Chemists (method 900.02, 994.12, 996.06, 996.01) (2005). Gaithersburg, Maryland.

AOAC. (2011). Standard Format and Guidance for AOAC Standard Method Performance Requirement (SMPR) Documents. Association of Official Analytical Chemists International.

Benassi, V. de T., Benassi, M. de T., \& Prudencio, S. H. (2011). Brazilian soybean cultivars: characteristics for tofu production and acceptance by the consumer market. Semina: Ciências Agrárias, 32(Suplp), 1901-1914. Retrieved from https://doi.org/10.5433/1679-0359.2011v32Suplp1901

Benassi, Várea, G. S., \& Prudencio, S. H. (2012). Tofus from different soybean cultivars: Sensory profile and correlation with instrumental and chemical composition measures. Alimentos e Nutrição, 23(4), 555-565.

Brand-Williams, W., Cuvelier, M. E., \& Berset, C. (1995). Use of a free radical method to evaluate antioxidant activity. LWT - Food Science and Technology, 28(1), 25-30. Retrieved from https://doi.org/10.1016/S0023-6438(95)80008-5

Brasil. Normative Instruction $n^{\circ}$ 60, 23 december 2019. Establishes lists of microbiological standards for foods (2019).

Brasil. RDC N³31, 23 december 2019. Provides for the microbiological standards of foods and their application. (2019).

Campos, R., Guerra, R., Aguilar, M., Ventura, O., \& Camacho, L. (1990). Chemical characterization of proteases extracted from wild thistle (Cynara cardunculus). Food Chemistry, 35(2), 89-97. Retrieved from https://doi.org/https://doi.org/10.1016/0308-8146(90)90023-W

Cantelli, K. C., Schmitd, J. T., Oliveira, M. A. de., Steffens, J., Steffens, C., Leite, R. S., \& Carrão-Panizzi, M. C. (2017). Soybean genetic lines sprouts: evaluation of physicochemical properties. Brazilian Journal of Food Technology, 20. Retrieved from https://doi.org/10.1590/1981-6723.7416

Cao, F.-H., Li, X.-J., Luo, S.-Z., Mu, D.-D., Zhong, X.-Y., Jiang, S.-T., ... Zhao, Y.-Y. (2017). Effects of organic acid coagulants on the physical properties of and chemical interactions in tofu. LWT - Food Science and Technology, 85, 58-65. Retrieved from https://doi.org/https://doi.org/10.1016/j.lwt.2017.07.005

Charney, J., \& Tomarelli, R. M. (1947). A colorimetric method for the determination of the proteolytic activity of duodenal juice. Journal of Biological Chemistry, 171(2), 501-505. Retrieved from https://doi.org/https://doi.org/10.1016/S0021-9258(17)41059-3

Dahmer, A. M., Rigo, A. A., Steffens, J., Steffens, C., \& Carrão-Panizzi, M. C. (2018). Thermal treatment for soybean flour processing with high-quality color and reduced Kunitz trypsin inhibitor. Journal of Food Process Engineering, 41(8), e12925. Retrieved from https://doi.org/10.1111/jfpe.12925

Dahmer, A. M., Rigo, A. A., Valduga, E., Steffens, J., Steffens, C., \& Carrão-Panizzi, M. C. (2020). Quality characteristics of rotative-type biscuits free of gluten prepared with soya flour and cassava starch. Current Nutrition \& Food Science, 16(2), 176-184. Retrieved from https://doi.org/10.2174/1573401314666181107100912

Ellis, R., \& Morris, E. R. (1986). Appropriate resin selection for rapid phytate analysis by ion-exchange chromatography. Cereal Chemistry., 63(1), 58-59.

Evans, D. E., Tsukamoto, C., \& Nielsen, N. C. (1997). A small scale method for the production of soymilk and silken tofu. Crop Science, 37(5), $1463-1471$. Retrieved from https://doi.org/10.2135/cropsci1997.0011183X003700050008x

Faion, A. M., Menegotto, A. L. L., Fernandes, I. A., Steffens, C., Steffens, J., \& Valduga, E. (2020). Production of Serra da Estrela cheese from ultrafiltered sheep's milk. Emirates Journal of Food and Agriculture, 384. Retrieved from https://doi.org/10.9755/ejfa.2020.v32.i5.2109

Foegeding, E. A., \& Drake, M. A. (2007). Invited review: sensory and mechanical properties of cheese texture. Journal of Dairy Science, 90(4), 1611-1624. Retrieved from https://doi.org/10.3168/jds.2006-703

Gominho, J., Curt, M. D., Lourenço, A., Fernández, J., \& Pereira, H. (2018). Cynara cardunculus L. as a biomass and multi-purpose crop: A review of 30 years of research. Biomass and Bioenergy, 109, 257-275. Retrieved from https://doi.org/10.1016/j.biombioe.2018.01.001 
Gu, E.-J., Kim, D. W., Jang, G.-J., Song, S. H., Lee, J.-I., Lee, S. B., ... Kim, H.-J. (2017). Mass-based metabolomic analysis of soybean sprouts during germination. Food Chemistry, 217, 311-319. Retrieved from https://doi.org/10.1016/j.foodchem.2016.08.113

Hamerstrand, G. E., Black, L. T., \& Glover, J. D. (1981). Trypsin inhibitors in soy products: modification of the standard analytical procedure. Cereal Chemistry, 51, 42-45.

Hassan, A. N., Frank, J. F., Schmidt, K. A., \& Shalabi, S. I. (1996). Textural properties of yogurt made with encapsulated nonropy lactic cultures. Journal of Dairy Science, 79(12), 2098-2103. Retrieved from https://doi.org/https://doi.org/10.3168/jds.S0022-0302(96)76583-9

IAL. (2008). Instituto Adolfo Lutz. Métodos físico-químicos para análise de alimentos. Métodos físicos-quimicos para análise de Alimentos. Retrieved from https://doi.org/10.1017/CBO9781107415324.004

Jayasena, V., Tah, W. Y., \& Nasar-Abbas, S. M. (2014). Effect of coagulant type and concentration on the yield and quality of soy-lupin tofu. Quality Assurance and Safety of Crops \& Foods, 6(2), 159-166. Retrieved from https://doi.org/10.3920/QAS2012.0176

Joo, K. H., \& Cavender, G. A. (2020). Investigation of tofu products coagulated with trimagnesium citrate as a novel alternative to nigari and gypsum: Comparison of physical properties and consumer preference. LWT, 118, 108819. Retrieved from https://doi.org/10.1016/j.lwt.2019.108819

Jun, J., Jung, M., Jeong, I., Kim, G., Sim, J., Nam, S., \& Kim, B. (2019). Effects of crab shell extract as a coagulant on the textural and sensorial properties of tofu (soybean curd). Food Science \& Nutrition, 7(2), 547-553. Retrieved from https://doi.org/10.1002/fsn3.837

Khoder, R. M., Yin, T., Liu, R., Xiong, S., You, J., Hu, Y., \& Huang, Q. (2020). Effects of nano fish bone on gelling properties of tofu gel coagulated by citric acid. Food Chemistry, 332, 127401. Retrieved from https://doi.org/10.1016/j.foodchem.2020.127401

Kumar, V., Rani, A., Rajpal, S., Srivastava, G., Ramesh, A., \& Joshi, O. P. (2005). Phytic acid in Indian soybean: genotypic variability and influence of growing location. Journal of the Science of Food and Agriculture, 85(9), 1523-1526. Retrieved from https://doi.org/10.1002/jsfa.2151

Li, L., Wang, C., Li, K., Qin, W., Wu, D., Hu, B., ... Zhang, Q. (2021). Influence of soybean protein isolate-dextran conjugates on the characteristics of glucono- $\delta$-lactone-induced tofu. LWT, 139, 110588. Retrieved from https://doi.org/10.1016/j.lwt.2020.110588

Li, M., Chen, F., Yang, B., Lai, S., Yang, H., Liu, K., ... Deng, Y. (2015). Preparation of organic tofu using organic compatible magnesium chloride incorporated with polysaccharide coagulants. Food Chemistry, 167, 168-174. Retrieved from https://doi.org/10.1016/j.foodchem.2014.06.102

Losado, V. A. M., Cantelli, K. C., Steffens, J., Steffens, C., \& Carrão-Panizzi, M. C. (2018). Improvement in soybean sprouts production with ultrasound power. Boletim Centro de Pesquisa de Processamento de Alimentos, 35(2), 1-9. Retrieved from https://doi.org/10.5380/bceppa.v35i2.60274

McGuire, R. G. (1992). Reporting of objective color measurements. HortScience HortSci, 27(12), 1254-1255. Retrieved from https://doi.org/10.21273/HORTSCI.27.12.1254

Miñones Conde, J., \& Rodríguez Patino, J. M. (2007). The effect of enzymatic treatment of a sunflower protein isolate on the rate of adsorption at the airwater interface. Journal of Food Engineering, 78(3), 1001-1009. Retrieved from https://doi.org/https://doi.org/10.1016/j.jfoodeng.2005.12.013

Miranda, A., \& Fraga, C. (2006). Free radical scavenger activity: determination of the antioxidant profile of bioactive substances. In Practical Studies for Medicinal Chemistry.

Nikolić, Z., Petrović, G., Panković, D., Ignjatov, M., Marinković, D., Stojanović, M., \& Đorđević, V. (2017). Threshold level and traceability of roundup ready soybean in tofu production. Food Technology and Biotechnology, 55(4), 439-444. Retrieved from https://doi.org/10.17113/ftb.55.04.17.5192

Olguin, M. C., Hisano, N., D’Ottavio, A. E., Zingale, M. I., Revelant, G. C., \& Calderari, S. A. (2003). Nutritional and antinutritional aspects of an Argentinian soy flour assessed on weanling rats. Journal of Food Composition and Analysis, 16(4), 441-449. Retrieved from https://doi.org/https://doi.org/10.1016/S0889-1575(03)00005-X

Poysa, V., \& Woodrow, L. (2002). Stability of soybean seed composition and its effect on soymilk and tofu yield and quality. Food Research International, 35(4), 337-345. Retrieved from https://doi.org/https://doi.org/10.1016/S0963-9969(01)00125-9

Queiroz, M. I., \& Treptow, R. O. (2006). Análise sensorial para avaliação da qualidade dos alimentos. Editora FURG - Fundação Universidade Federal do Rio Grande.

Rigo, A. A., Dahmer, A. M., Steffens, C., Steffens, J., \& Carrão-Panizzi, M. C. (2015). Characterization of soybean cultivars genetically improved for human consumption. ETP International Journal of Food Engineering, 1(1), 1-7. Retrieved from https://doi.org/10.18178/ijfe.1.1.1-7

Scherer, G. C. R. da S., Ambrósio, N., Fernandes, I. A., Steffens, C., Valduga, E., Carrão-Panizzi, M. C., ... Steffens, J. (2021). Maximization of maceration step of obtaining water-soluble soy extract process. Brazilian Journal of Development, 7(3), 28197-28215. Retrieved from https://doi.org/10.34117/bjdv7n3507

Schmidt, J., Cantelli, K. C., Steffens, C., Steffens, J., \& Zeni, J. (2017). Effects of vegetable coagulants in the production and storage of tofu. Global Science and Technology, 10(01), 188-198.

Shen, Y.-R., \& Kuo, M.-I. (2017). Effects of different carrageenan types on the rheological and water-holding properties of tofu. LWT, 78, 122-128. Retrieved from https://doi.org/10.1016/j.lwt.2016.12.038

Silvestri, J. D. F., Paroul, N., Czyewski, E., Lerin, L., Rotava, I., Cansian, R. L., ... Treichel, H. (2010). Chemical composition and antioxidant and antibacterial activities of clove essential oil (Eugenia caryophyllata Thunb). Revista Ceres, 57(5), 589-594. Retrieved from https://doi.org/10.1590/s0034$737 \times 2010000500004$

Stanojevic, S. P., Barac, M. B., Pesic, M. B., \& Vucelic-Radovic, B. V. (2011). Assessment of soy genotype and processing method on quality of soybean tofu. Journal of Agricultural and Food Chemistry, 59(13), 7368-7376. Retrieved from https://doi.org/10.1021/jf2006672 
Research, Society and Development, v. 10, n. 16, e207101623576, 2021

(CC BY 4.0) | ISSN 2525-3409 | DOI: http://dx.doi.org/10.33448/rsd-v10i16.23576

Stanojevic, S. P., Barać, M. B., Pešić, M. B., \& Vucelic-Radovic, B. V. (2020). Protein composition and textural properties of inulin-enriched tofu produced by hydrothermal process. LWT, 126, 109309. Retrieved from https://doi.org/10.1016/j.lwt.2020.109309

Tres, G., Steffens, J., \& Steffens, C. (2019). Tofu obtained with lemon coagulant and soybean concentrate. Revista Tecnológica, 28(1), 85-100. Retrieved from https://doi.org/10.4025/revtecnol.v28i1.48693

Ullah, I., Hu, Y., You, J., Yin, T., Xiong, S., Din, Z., ... Liu, R. (2019). Influence of okara dietary fiber with varying particle sizes on gelling properties, water state and microstructure of tofu gel. Food Hydrocolloids, 89, 512-522. Retrieved from https://doi.org/https://doi.org/10.1016/j.foodhyd.2018.11.006

Yang, Jiang, S., \& Li, L. (2021). The gel properties and gastric digestion kinetics of a novel lactic acid bacteria fermented tofu: Focusing on the effects of transglutaminase. LWT, 143, 110998. Retrieved from https://doi.org/10.1016/j.lwt.2021.110998

Yang, Y., Wang, B., Fu, Y., Shi, Y., Chen, F., Guan, H., ... Zhang, N. (2021). HS-GC-IMS with PCA to analyze volatile flavor compounds across different production stages of fermented soybean whey tofu. Food Chemistry, 346, 128880. Retrieved from https://doi.org/10.1016/j.foodchem.2020.128880

Yin, L., Zhang, Y., Wu, H., Wang, Z., Dai, Y., Zhou, J., ... Xia, X. (2020). Improvement of the phenolic content, antioxidant activity, and nutritional quality of tofu fermented with Actinomucor elegans. LWT, 133, 110087. Retrieved from https://doi.org/10.1016/j.1wt.2020.110087

Yuan, S., \& Chang, S. K. C. (2007). Texture profile of tofu as affected by instron parameters and sample preparation, and correlations of instron hardness and springiness with sensory scores. Journal of Food Science, 72(2), S136-S145. Retrieved from https://doi.org/10.1111/j.1750-3841.2006.00263.x 